This item was submitted to Loughborough's Research Repository by the author.

Items in Figshare are protected by copyright, with all rights reserved, unless otherwise indicated.

\title{
The media and football supporters: a changing relationship
}

PLEASE CITE THE PUBLISHED VERSION

http://dx.doi.org/10.1177/0163443710393866

PUBLISHER

Sage $($ The Author

VERSION

AM (Accepted Manuscript)

LICENCE

CC BY-NC-ND 4.0

REPOSITORY RECORD

Cleland, Jamie. 2019. "The Media and Football Supporters: A Changing Relationship". figshare. https://hdl.handle.net/2134/12127. 
This item was submitted to Loughborough's Institutional Repository (https://dspace.lboro.ac.uk/) by the author and is made available under the following Creative Commons Licence conditions.

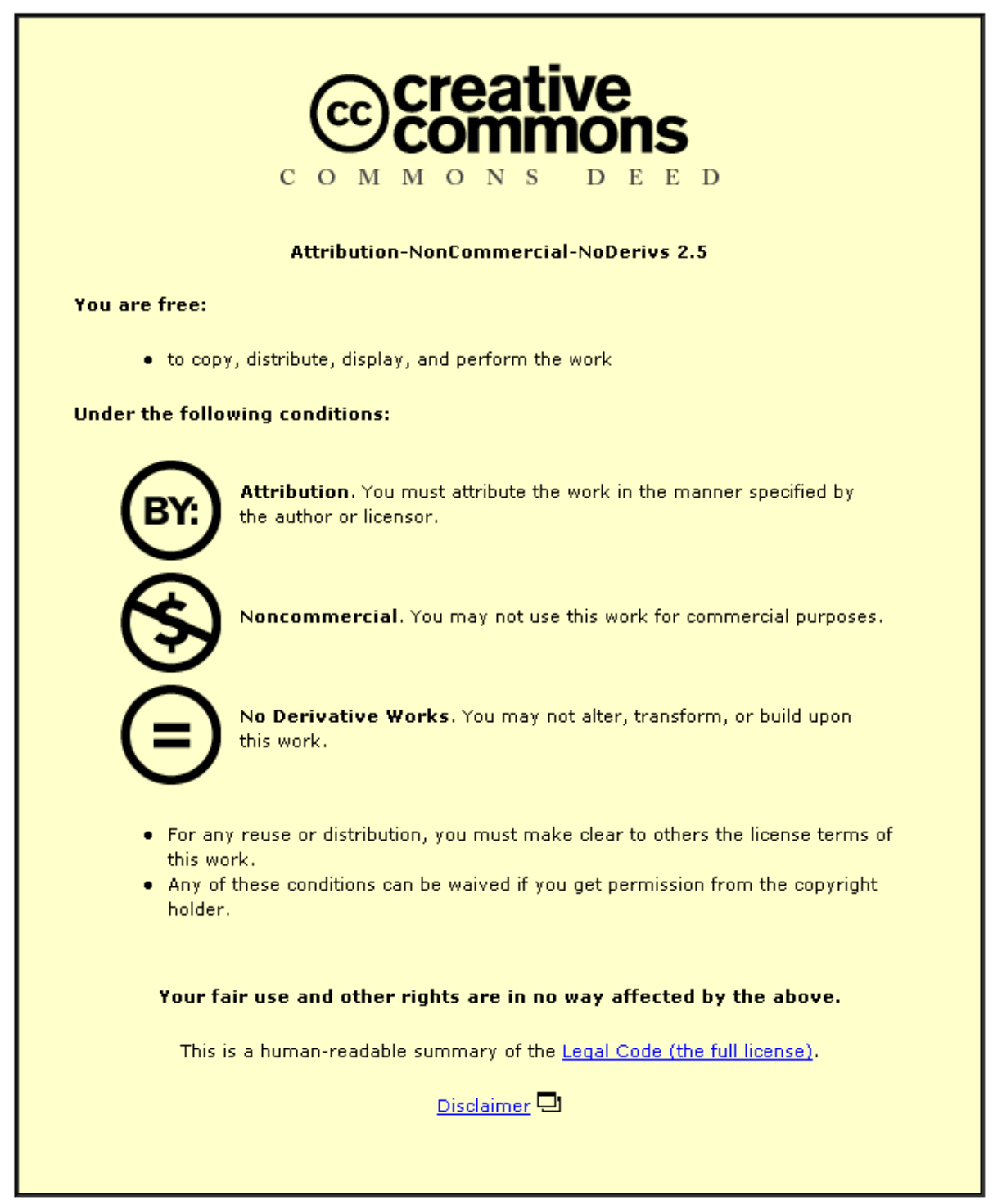

For the full text of this licence, please go to: http://creativecommons.org/licenses/by-nc-nd/2.5/ 


\title{
'The Media and Football Supporters: A Changing Relationship'
}

\begin{abstract}
The development of 'new' media at the end of the 1980s and early 1990s has radically changed the relationship between the media and football supporters. Firstly, a growth in media sources created a very competitive media environment and, secondly, led to greater interaction between the media and its audience. Drawing on forty seven semi-structured interviews with media personnel and eight hundred and twenty seven questionnaires completed by supporters at four football clubs, this article assesses how fans consume the many media sources that now exist and the level of involvement for supporters in the media. The results indicated a balance of consumption between 'old' and 'new' media as well as highlighting the contrasting strategies each media source had put in place to involve supporters. The article concludes by suggesting that there remains a place for those media sources which involve their target audience.
\end{abstract}

Keywords: football; media; active/passive supporters; clubs; relationship; two-way dialogue

\section{Introduction}

Since the late 1980s, the development of what Boyle and Haynes (2004) term 'new' media (satellite television, the Internet and mobile phones) and the re-structuring of 'old' or 'traditional' media (local and national newspapers, local and national radio and local television) has affected the media's relationship with football supporters. Subsequently, the purpose of this article is to build on the work of Fiske (1989) and Abercrombie and Longhurst (1998) and provide evidence of the changes to the mediafan relationship as we enter more of an 'interactive' age of media-audience engagement. The article shall argue that analysing both media consumption and the level of discourse between the media (and football clubs) and supporters are crucial to understanding the evolving media-audience debate.

It shall also be argued that the media-fan relationship is being strengthened due to the increasing number of 'active' fans (those who actively use media texts such as radio phone-ins and possibly produce their own texts such as fanzines) at the expense of 'passive' fans (those whose support is mediated through consumer products and television and other forms of media). For example, many media sources are increasingly attempting ways of encouraging supporters to actively interact with them. This can be seen with the growth in television and radio phone-in programmes (both local and national) and the development of message boards on official, unofficial (such as those created by supporters of specific clubs) and independent (such as BBC Sport and Sky Sports) websites. 
The research presented in this article is based on data collected at four football clubs (Aston Villa, Birmingham City, Coventry City and Northampton Town) and has two objectives: (a) to examine how fans consume modern media and (b) to analyse the extent to which 'new' and 'old' media have adopted strategies to involve supporters in two-way dialogue. For the purposes of this article, internal media refers to media sources that clubs control such as the match day programme and the official club website and external media refers to media sources that fall outside of clubs control such as the local and national media.

To assist in addressing the second research objective, the media-fan relationship is conceptualised as a continuum; often referred to as a 'one-axis model' in political science through the content analysis of documents, interviews and survey work (see Laver and Garry 2000; Benoit and Laver 2006). In applying this approach, the changes in the media-fan relationship are analysed in terms of the opportunities provided by the media for greater supporter involvement as this may not be the same for each media source: ${ }^{1}$

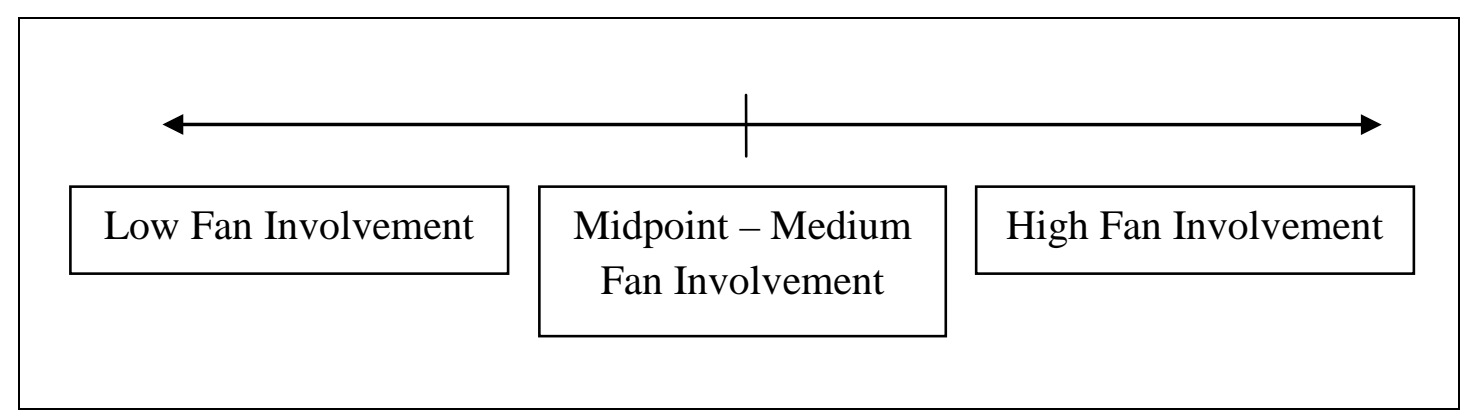

\section{The Media-Fan Relationship}

The media-fan relationship is a historic one and began with local newspapers providing limited opportunities for fans to air their views through a letters page (Haynes 1995). Although the introduction of radio and television helped the relationship during the twentieth century, the level of supporter involvement remained limited for a long period of time. However, since the 1980s, the diversity of the media has changed this relationship and consists of two central features that shall be presented here. The first centres on how the media changed their communication strategy as the industry became more competitive to improve their relationship with fans to increase sales and/or readers, viewers and listener levels. The second outlines that as fans became more 'active' in their consumption of media texts (as suggested 
by Fiske 1989 and Abercrombie and Longhurst 1998), the changes within the media have led to greater opportunities for fans to engage in two-way dialogue with an increasing number of sources.

The first feature in the modern media-fan relationship concentrates on the changing communication strategy of the media to remain competitive. The successful bid by BSkyB in 1992 for exclusive live television coverage of the newly formed Premier League immediately had repercussions on the traditional television-fan relationship. For those fans who could afford the costs of subscription, regular football all over the world became available to the 'armchair viewer' (Wenner 1998; Williams 1999, 2006). Currently, sports fans in England who can afford or choose to subscribe to satellite or cable television have numerous sports channels to select from, with one of the channels available, Sky Sports News, providing news and information about sport twenty-four hours a day. This has helped transform the television-fan relationship as fans can engage with sports stories as they immediately occur and contribute to studio debates via text, phone or e-mail.

Whilst the relationship between television and supporters has changed, other 'traditional' media sources have also changed as the industry became more competitive. At a time of decreasing sales for many newspapers the coverage they devote to football has increased dramatically to try and boost readership numbers. However, it would be wrong to assume that this fall in newspaper sales is a circulation crisis, as newspapers now compete with many different media outlets in providing news and information. To remain competitive, national newspapers now dedicate whole sections to football with nearly every national tabloid newspaper providing a pull-out football section on a Sunday and Monday, and the main broadsheet papers publishing a separate sport section (focusing mainly on football) throughout the week.

A further development that has aided the relationship has been the increasing live commentary of matches on local and national radio. Not only has this widened the opportunity for fans of all clubs to listen to matches, but the majority also encourage fans to phone-in and discuss either the result of the game or the build up to it. Whilst Radio Five Live mainly broadcasts and concentrates discussion on Premier League matches, local radio stations have provided an important link with supporters, especially those in the lower leagues. Indeed, the success of local radio has led to a level of competition amongst local radio stations, who each try and maximise their potential audience by broadcasting the matches of teams in the areas that they serve. 
This change in strategy by the local media is also supported by research carried out by Gunter et al. (1994) who found that when researching local news, 40 per cent of the public received this through newspapers compared to 35 per cent through television. Thus, even though they did not cover football specifically, these results still provide an interesting insight into the continued importance of the local press in a mass media world. In similar research, O’Sullivan et al. (2003) found that in the late 1990s, sources of local news were gathered first through newspapers, then television followed by radio. One possible reason for this could be that the local newspaper can reach over 80 per cent of most 'local' households, with the Internet providing an opportunity for all local households to access local news online.

One media-fan study, conducted by the University of Liverpool's Football Research Unit (1999), examined the relationship between Liverpool and Everton supporters and the local media. Whilst the local evening newspaper (the Daily Echo) was the most important source for supporters, one of the main conclusions drawn from this study was that local radio also played an important role. What this suggests is that although there have been advances in the relationship between 'new' media and football, many football fans still prefer to gather news and information from traditional sources, such as local evening newspapers and local radio, rather than ‘niche’ media.

Despite 'traditional' sources remaining an important part of modern football, it should be noted that one of the clear reasons behind the rapidly changing media-fan relationship is a result of the Internet. Highlighting the impact of 'new' media like the Internet and satellite television, Social Trends (2004) reported that 45 per cent of households had both a satellite receiver and Internet access during 2002/03. This was in comparison to 1999/2000, where only 20 per cent of households had Internet access and 30 per cent had a satellite receiver. Applying the growth of the Internet to football, whilst the 2001 Sir Norman Chester Centre for Football Research (SNCCFR) stated that 73 per cent of supporters had online access, the Premier League survey (2005/06) stated this had increased to 91 per cent.

The Internet has changed the environment of communication as it provides an internal channel where sports organisations can bypass external media organisations and communicate directly with their fans (Spielger 1996; Beech et al. 2000b). Not surprisingly, all football clubs now utilise the Internet as a direct channel for accessing their fans and providing them with the necessary information. This process 
allows fans with online capabilities to access up-to-date information by accessing the official club website, with Turner (1999) suggesting that this can only aid the club-fan relationship.

The way modern media sources communicate and increasingly interact with supporters is therefore the second feature in the evolving media-fan relationship. According to Horne (2006: 62), research into the influence of the media on the audience began during the late 1970s and early 1980s as audiences started to be treated as fans who 'interacted with the material they viewed, read and listened to'. Similarly, Curran (2002: 7) also outlines the 1970s as the period when phone-in programmes and studio audience participation began and 'gave increased opportunities for members of the general public to contribute to collective dialogue' about matters relevant to society, such as football.

One significant contributor to the study of the media and popular culture is John Fiske. Fiske stated that 'popular culture is made by the people, not produced by the culture industry' and rather than being passive in their consumption people are, in fact, producers who 'embody a shifting set of allegiances that cross all social categories' (1989: 24). According to Fiske, it was the ability of popular texts (which he termed polysemic), carrying various meanings which allowed fans to be able to construct alternative readings and interpretations of such texts and thus keep football at the forefront of popular culture. By examining texts in this way, Fiske stated that fans were therefore different to 'normal' audiences because of their strong forms of attachment.

In their analysis of the changing media-audience relationship, Abercrombie and Longhurst (1998) highlighted three chronological paradigms: behavioural; incorporation/resistance; and spectacle/performance. Abercrombie and Longhurst argue that behavioural occurred when the audience accepted or passively absorbed information that was provided to them by the media. This was then superseded by the incorporation/resistance paradigm because the audience was viewed as more active in their consumption. Finally, in modern times, a spectacle/performance paradigm is evident as the audience is becoming more 'skilled' in their consumption of the many media sources that now exist.

This latter paradigm has found some support with research being undertaken on how the 'audience' (or fans) approach the media and engage with the range of media texts that are now available (Mansell 2004; Jenkins 2006). Whilst the first 
series of fan studies 'assumed a simple dichotomy of power, with producers on the one hand and fans on the other' (Sandvoss 2005: 154), the relationship has changed as a result of both the diversity of the media and the changing nature of modern fans. Laughey (2007: 169-170) provides a useful illustration of the complexity of this debate as 'new' media such as the Internet 'provide media-literate individuals with the tools to encode - not only decode - their own mediated messages by creating websites and so on'.

Part of these views started with the perception that the nature of the audience (fans) might be changing from 'passive' to 'active' in their consumption of news and information (Redhead 1993; Haynes 1995; Crawford 2004). Indeed, the changes within the media have enabled some fans to become 'active' and, more recently, 'interactive' as the opportunities to engage with the media have increased (Ross and Nightingale 2003; Blain and Bernstein 2003; Williams 2006). As presented earlier, this applies to all media sources as older sources have been forced to adapt their strategy and look at ways of interacting with supporters.

Although research on the increasing level of two-way dialogue between various media sources and football supporters is limited, for those supporters who do not produce their own texts, the developments that have occurred within the media have provided an opportunity to connect with football supporters in various ways. This view is supported in a study carried out on mainly Rangers and Celtic supporters by O’Donnell (2003: 211), which highlighted the increasing interactivity between a radio station (Radio Clyde) and its listeners. Two-way dialogue between the host and the supporters is a regular feature of the programme and its success is evident with over 300,000 people regularly listening to the content being discussed. One reason for this improvement could be because of the new technological advances in radio, such as listening via the web or digitally, but it could also be because of the increasing level of interactivity between radio and the public. An example of this is the increasing development of dedicated sport radio stations, such as Talk Sport, where the public are invited to telephone the radio station and discuss sport-related matters or topics.

Furthermore, the Internet gives many fans the opportunity to actively air their views on message boards. However, despite many clubs making substantial progress with their official websites, one criticism often raised is the lack of an interactive experience when compared to many unofficial websites. For instance, research carried 
out by Beech et al. (2000a) found that whilst unofficial websites dealt with speculation and anecdotal information, they generally gave supporters a better interactive experience by developing chat rooms. Therefore, although two-way dialogue is evident amongst unofficial websites, Beech et al. found that there was little evidence of attempts by clubs to forge meaningful links or dialogue with supporters through the official website. ${ }^{2}$

With regards to the evolving relationship between other media sources and fans, the relationship between BSkyB and its viewers has been further enhanced with the introduction of a phone-in programme called 'You're on Sky Sports'. Likewise, newspapers (often local) now publish a series of 'fan' related match reviews and letters to try and include them more in the discussion surrounding clubs. Again, the content being used in each of these services is crucial, 'as simply delivering news and information on football or providing chat rooms for fans to engage with each other may not automatically guarantee an audience for such content' (Boyle and Haynes 2004: 141). Whilst these media services have tried to create new experiences for football supporters, it has been suggested that the changes are a result of the increasing commodification of football fandom:

\footnotetext{
"new media services are establishing new relationships between the interests of global capitalism and football as a form of popular culture. Crucially, the relationship between football and new media is viewed as being increasingly intertwined in a complex web of relationships between football authorities, players and agents, sponsors and advertisers, the media, telecommunications companies and fans”. (Boyle and Haynes 2004: 139)
}

\section{Method}

The methods of data collection and analysis adopted for this article were part of wider research which examined the club-fan relationship, the club-media relationship and the media-fan relationship. The focus of this article is on the media-fan relationship. Data was collected at four football clubs (Aston Villa, Birmingham City, Coventry City and Northampton Town) during the 2002/03 season. Each club was selected as it had a different amount of media sources (both internal and external) available to communicate and interact with supporters and had a wide ranging fan base (Aston Villa's average attendance over the season was over 34,000 compared to 5,000 at Northampton Town). Indeed, the differences in potential fan base and local media utilisation were noticeable through the number of people living in each city. 
According to the 2001 Census, for example, nearly one million people lived in the city of Birmingham (977,087), with 300,848 living in Coventry and 194,458 living in Northampton.

To analyse the media-fan relationship at each club a multi-method approach, combining both qualitative and quantitative methods was used and was split into two large scale methods of collecting data. Firstly, once consent had been agreed, fortyseven intensive semi-structured interviews of relevant club officials (those involved in the communication process), unofficial external personnel (fanzine editors, unofficial website editors and supporters' group representatives) and local media personnel (local journalists) was carried out. The questions centred on two main themes, both of which focused on the two research objectives: the changing nature of the media environment and the ways in which they engaged with supporters.

Secondly, an extensive questionnaire survey of eight hundred and twentyseven supporters was also undertaken. In terms of quantitatively assessing the two research objectives, the aim of the survey was to find out what media sources supporters at all four clubs used to gather news and information and what was their single most important source of news and information. The results would then highlight the level of modern media consumption by supporters and whether there had been a shift towards more 'interactive' media.

The semi-structured interviews were analysed through a manual form of content analysis. Although content analysis can be used quantitatively to count themes in numerical terms, each subject's responses were coded and categorised, thus providing more depth to the research. As suggested by Miles and Huberman (1984: 9), once all of the data had been themed into categories, the analysis began to identify 'patterns and processes, commonalities and differences' within the collected data. The questionnaire survey analysed the responses through the use of frequencies and cross tabulations.

\section{Case Study Findings}

As a result of the changing role and function of the media since the 1980s there has been a big increase in the number and range of internal and external media sources available to communicate and interact with football supporters. In reviewing the changing media-fan landscape, during the interview process the head of sport at 
Capital Gold radio in Birmingham highlighted the need for strategic attention to be paid to this rapidly evolving relationship:

Well it is different now [since the 1980s] because there are so many places to go for your information, you've got the club's official website...there's national and local newspapers, there's Talk Sport, Radio Five, there's BBC WM, there's us, there's Teletext, there's Ceefax, Clubcall, TeamTalk, you've got a million ways to get information. So I've thought to myself why should they come to me? Facts not fiction, tell them the truth, only deal in facts not fiction and get it to them quickly.

Similarly, the local football journalist for the local evening newspaper in Northampton (the Northampton Chronicle and Echo), believed that both fans and the media are changing, thus making the relationship more diverse and complex:

\begin{abstract}
I think it is because with all the different media now fans are just hungry for more and more information, whereas ten years ago they might have been happy just to see who was playing, who was injured and what the result was. Now they want to know everything about the club, they want to know what's happening on the financial side of things, they want to know how much players are earning, they want to know everything and it's our job along with everybody else [in the communication process] to try and give them information.
\end{abstract}

With regards to the first research objective, starting with Aston Villa, of the available 'local' print media sources available for fans to consume news and information on the club, there was a local evening newspaper (the Birmingham Evening Mail), a Saturday evening Sports Argus newspaper, a local morning broadsheet newspaper (the Birmingham Post) and a regional Sunday newspaper (the Sunday Mercury). There were also two local radio stations providing coverage on the club (Capital Gold/BRMB and BBC WM) and two local television stations (BBC and ITV). ${ }^{3}$ Nationally, the club also had coverage in national newspapers, radio, satellite television and a range of official and unofficial websites and fanzines. Internally, the club employed six people to communicate with supporters via an official website, a match day programme, a club magazine (Claret and Blue), a digital radio station (The 'Villan'), a mobile phone texting service and regular newsletters and mail shots.

Similarly to Aston Villa, Birmingham City had the same number of local and national media sources available to communicate with its supporters, although the only difference with the external media was that it had an exclusive local radio commentary deal with Capital Gold/BRMB on all its home and away matches. In comparison to Aston Villa, Birmingham City and the other two clubs had a low number of both staff and internal sources for fans to utilise and engage with, including 
an official club website, a match day programme, mobile phone texting, newsletters and mail shots.

Coventry City had a large amount of coverage in the local evening newspaper (the Coventry Evening Telegraph), a Saturday Pink evening newspaper, three local radio stations (Mercia, Kix and BBC Coventry and Warwickshire), of which BBC Coventry and Warwickshire had an exclusive commentary deal on all home and away matches, two television stations (BBC and ITV) and a regional Sunday newspaper (the Sunday Mercury). Outside of the local media the club also had the same range of national media sources as Aston Villa and Birmingham City, although they tended to focus more on clubs that played in the Premier League.

At Northampton Town, in terms of the local media, the club also had a local evening newspaper to utilise (the Northampton Chronicle and Echo), a local radio station that commentated on the sport playing away if both teams played at the same time (BBC Radio Northampton), and two local television stations (BBC and Anglia). Unlike the other three clubs, no Saturday evening sports newspaper was sold in Northampton. Nationally, Northampton Town also had the same media sources available to communicate with its supporters as the other three clubs, although not surprisingly the coverage provided to clubs in lower-league football was severely limited.

Therefore, apart from Aston Villa, the other three clubs had a similar amount of media sources, both internal and external, to utilise when communicating with their supporters. So, to gain a comprehensive understanding of the relationship between the modern media sources and the supporters that used them, part of the questionnaire survey asked the supporters at each club to list all of the media sources they used to gather news and information. To summarise these results, Table 1 highlights the top five most utilised sources at each club with the percentage in brackets:

Table 1. Five Most Utilised Sources for News and Information at Each Club (source: Author's questionnaire survey)

\begin{tabular}{|c|c|c|c|c|}
\hline & Aston Villa & $\begin{array}{c}\text { Birmingham } \\
\text { City }\end{array}$ & Coventry City & $\begin{array}{c}\text { Northampton } \\
\text { Town }\end{array}$ \\
\hline $\mathbf{1}^{\text {st }}$ Most & Official Club & Birmingham & Coventry & Northampton \\
Accessed & Website (69\%) & Evening Mail & Evening & Chronicle and \\
Source & & Newspaper & Telegraph & Echo \\
& & $(77 \%)$ & Newspaper & Newspaper \\
& & & $(75 \%)$ & $(79 \%)$ \\
\hline
\end{tabular}




\begin{tabular}{|c|c|c|c|c|}
\hline $\begin{array}{c}2^{\text {nd }} \text { Most } \\
\text { Accessed } \\
\text { Source }\end{array}$ & $\begin{array}{c}\text { Birmingham } \\
\text { Evening Mail } \\
\text { Newspaper } \\
(68 \%)\end{array}$ & $\begin{array}{c}\text { Official Club } \\
\text { Website (75\%) }\end{array}$ & $\begin{array}{c}\text { Official Club } \\
\text { Website and } \\
\text { National } \\
\text { Newspapers } \\
(69 \%)\end{array}$ & $\begin{array}{c}\text { Official Club } \\
\text { Website (69\%) }\end{array}$ \\
\hline $\begin{array}{c}3^{\text {rd }} \text { Most } \\
\text { Accessed } \\
\text { Source }\end{array}$ & $\begin{array}{c}\text { Teletext/Ceefax } \\
(67 \%)\end{array}$ & $\begin{array}{c}\text { Teletext/Ceefax } \\
(57 \%)\end{array}$ & $\begin{array}{c}\text { BBC Coventry } \\
\text { and } \\
\text { Warwickshire } \\
\text { Radio (56\%) }\end{array}$ & $\begin{array}{c}\text { Teletext/Ceefax } \\
\text { (66\%) }\end{array}$ \\
\hline $\begin{array}{c}4^{\text {th }} \text { Most } \\
\text { Accessed } \\
\text { Source }\end{array}$ & $\begin{array}{c}\text { National } \\
\text { Newspapers } \\
(66 \%)\end{array}$ & $\begin{array}{c}\text { National } \\
\text { Newspapers } \\
(53 \%)\end{array}$ & $\begin{array}{c}\text { Teletext/Ceefax } \\
(52 \%)\end{array}$ & $\begin{array}{c}\text { BBC Radio } \\
\text { Northampton } \\
(55 \%)\end{array}$ \\
\hline $\begin{array}{c}5^{\text {th }} \text { Most } \\
\text { Accessed } \\
\text { Source }\end{array}$ & $\begin{array}{c}\text { Satellite } \\
\text { Television } \\
(50 \%)\end{array}$ & $\begin{array}{c}\text { Capital } \\
\text { Gold/BRMB } \\
\text { Radio and the } \\
\text { Sports Argus } \\
\text { Newspaper } \\
(50 \%)\end{array}$ & $\begin{array}{c}\text { Saturday Pink } \\
\text { Newspaper } \\
(51 \%)\end{array}$ & $\begin{array}{c}\text { Match Day } \\
\text { Programme } \\
\text { (54\%) }\end{array}$ \\
\hline
\end{tabular}

These results indicate that there was an importance placed on more national sources to support its national profile at Aston Villa compared to Northampton Town, where more local and internal club sources were viewed by supporters as being important. Promotion to the Premier League just prior to the research beginning in May 2002 could be one possible explanation why Birmingham City supporters utilised a mix of national and local sources, whilst Coventry City fans also tended to use a mixture of both national and local sources to gather news and information on the club.

It is also noticeable how important both 'new' and 'old' sources of news and information were to the modern football supporter. At each of the four clubs, the 'oldest' source (the local evening newspaper) and one of the 'new' sources (the official website) were both in the top two most accessed sources, followed mainly by Teletext/Ceefax and national newspapers. Thus, even though some club officials dismissed any form of dependence on the external press during the interview process, the results suggested otherwise with all of the clubs relying on the local press to communicate with a large majority of its supporters. This theme also continued when the questionnaire survey asked supporters to name their single most important source of news and information (see Table 2 with the percentage in brackets). It outlines that for three out of the four clubs the external local evening newspaper was the number one source for news and information over the internal official club website. These results, therefore, reflect the continued traditional use of media sources by fans as 
they prefer mixed and comprehensive coverage of different kinds of news through traditional sources, highlighting the limits of 'niche' media. What this also highlights is that a number of fans remain passive and consume sources that suit them.

Table 2. Three Most Important Sources for News and Information at Each Club (source: Author's questionnaire survey)

\begin{tabular}{|c|c|c|c|c|}
\hline & Aston Villa & $\begin{array}{l}\text { Birmingham } \\
\text { City }\end{array}$ & Coventry City & $\begin{array}{c}\text { Northampton } \\
\text { Town }\end{array}$ \\
\hline $\begin{array}{c}1^{\text {st }} \text { Most } \\
\text { Important } \\
\text { Source }\end{array}$ & $\begin{array}{l}\text { Birmingham } \\
\text { Evening Mail } \\
\text { Newspaper } \\
(30 \%)\end{array}$ & $\begin{array}{l}\text { Birmingham } \\
\text { Evening Mail } \\
\text { Newspaper } \\
(37 \%)\end{array}$ & $\begin{array}{c}\text { Coventry } \\
\text { Evening } \\
\text { Telegraph } \\
\text { Newspaper } \\
(41 \%)\end{array}$ & $\begin{array}{c}\text { Official Club } \\
\text { Website (45\%) }\end{array}$ \\
\hline $\begin{array}{c}2^{\text {nd }} \text { Most } \\
\text { Important } \\
\text { Source }\end{array}$ & $\begin{array}{c}\text { Official Club } \\
\text { Website (26\%) }\end{array}$ & $\begin{array}{c}\text { Official Club } \\
\text { Website (35\%) }\end{array}$ & $\begin{array}{c}\text { Official Club } \\
\text { Website (29\%) }\end{array}$ & $\begin{array}{c}\text { Northampton } \\
\text { Chronicle and } \\
\text { Echo } \\
\text { Newspaper } \\
(37 \%)\end{array}$ \\
\hline $\begin{array}{c}3^{\text {rd }} \text { Most } \\
\text { Important } \\
\text { Source }\end{array}$ & $\begin{array}{c}\text { Satellite } \\
\text { Television (8\%) }\end{array}$ & $\begin{array}{c}\text { Unofficial } \\
\text { Websites (7\%) }\end{array}$ & $\begin{array}{c}\text { Unofficial } \\
\text { Websites (6\%) }\end{array}$ & $\begin{array}{l}\text { Match Day } \\
\text { Programme } \\
(5 \%)\end{array}$ \\
\hline
\end{tabular}

Despite Aston Villa having the largest number of internal sources available to its supporters, only the official website was ranked in the top three most important sources, with the club's national profile supported by the perceived importance of satellite television (BSkyB). Interestingly, at Aston Villa, Coventry City and Birmingham City, the local newspaper was still viewed as the most important local media source even though the local radio stations were recognised by a majority of supporters as effective platforms that provided them with more of an opportunity to get their opinion across. Strangely, at both Coventry City and Birmingham City, unofficial websites were ranked as the third most important source even though they did not appear in the top five most accessed sources for news and information (see Table 1). One of the reasons for this could be the increasing opportunities provided by these sources to engage in two-way dialogue and discuss the particular club with their fellow supporters pre- and post-match.

The only difference with the most important media source for supporters was at Northampton Town. One of the reasons for this could be that Northampton Saints Rugby Club commanded most of the back page headlines because of its status in 
rugby union and its greater fan base. Therefore, as a result of a lack of back page coverage, it was not surprising why the official club website was stated by Northampton Town supporters as being their most important source as it was the only source to provide unique coverage on the club. Indeed, the other main internal source for communicating with a large majority of supporters, the match day programme, was also found to play an important part. This makes Northampton Town the only club that had two internal sources ranked in the top three most important media, illustrating a lack of coverage and exposure in the wider external media.

With regards to the second research objective, as suggested by Beech et al. (2000a), Mansell (2004) and Jenkins (2006), the media-fan relationship was further enhanced when 'new' media quickly established the opportunity for two-way dialogue with supporters to discuss issues surrounding clubs. This became evident through the development of different Internet sites and dedicated television programmes like 'You're on Sky Sports'. Furthermore, 'new' media also forced 'old' media, such as newspapers and radio into establishing strategies which encouraged two-way dialogue with their readers and listeners. ${ }^{5}$ All of this has resulted in a number of academic studies concerning the change in fans from 'passive' to 'active' as they wanted to be more actively involved in the game (Abercrombie and Longhurst 1998; Crawford 2004; Sandvoss 2005; Laughey 2007). The extent to which this occurred for each media source and supporters at each club now forms the final basis of this article (see Figures 1-4).

Indeed, the opportunities created for two-way dialogue with supporters by the media was well supported amongst the supporter group representatives in this research with the liaison officer of the Aston Villa Supporters’ Trust stating:

I think supporters are starting to play their part...our views are just as valid [and] we have got a right to say we want this and we want that and we want things to change.

During the research process some internal and external sources regularly encouraged two-way dialogue with supporters throughout the season (a development supported by the Football Research Unit 1999; O’Donnell 2003; Boyle and Haynes 2004). Unofficial websites, not surprisingly, had a high level of supporter involvement across all four clubs but most other external sources (especially local ones) were also aided by the Internet. Whilst debating each club through the local press was not available every day, each source had message boards where discussions could continue and this 
supported their role further. However, the opportunity for fan involvement was not the case for every media source. The chief football writer at the Birmingham Post, for instance, stated:

I don't regard myself as having any responsibility to the fan, short to making sure what I write is accurate and truthful. Other than that I'll be as opinionated as possible, I'll dig as deep as I want to because I don't feel that sense of responsibility to them because I think it's the websites role now, club websites.

Assessing the level of supporter involvement for the internal sources at Aston Villa, the results supported research by Beech et al. (2000a) who outlined that a majority of clubs had failed to develop meaningful links or open up two-way dialogue with supporters. There were opportunities to engage with the official website on its message board service and to personally contact the club but the level of involvement was relatively low. Part of this became apparent through comments made by the official website editor at the club who said:

sometimes they [the supporters] raise points and say that I would appreciate a reply and then I will get into correspondence [with them] and there are some Villa fans, I'd say approaching fifty that I now correspond with on a regular basis because what they want out of the club is to feel they're being heard and being listened to.

This was also the case in allowing for two-way dialogue through fans' forums as they were only available to shareholders to attend. This strategy prevented an opportunity for a large majority of supporters to express their opinion. However, the digital radio station (The 'Villan') did provide opportunities for two-way dialogue through its phone-in programme after every first team match had finished and on a Monday evening and this option was well received by a number of supporters.

Externally at Aston Villa, most local media sources provided opportunities for supporters to interact and become involved in discussing the club (both through the normal platform and online). The Birmingham Evening Mail, for example, had developed a feature called 'Your Shout' where supporters were encouraged to make contact via e-mail, telephone or letter, some of which were then published. Similarly, on both local radio stations, BBC WM and Capital Gold/BRMB, opportunities were given on a Friday evening and after every match for supporters to phone-in. ${ }^{6}$ According to the sports editor at BBC WM, the aim of this change in strategy for local radio was to: 
encourage a forum for people to get their views across and hear other people's opinions' via e-mail, text messaging or telephone.

Therefore, based on the findings, the continuum assessing the overall level of supporter involvement for both internal and external media at Aston Villa is now presented in Figure 1:

Figure 1: Level of Supporter Involvement in Media Sources at Aston Villa

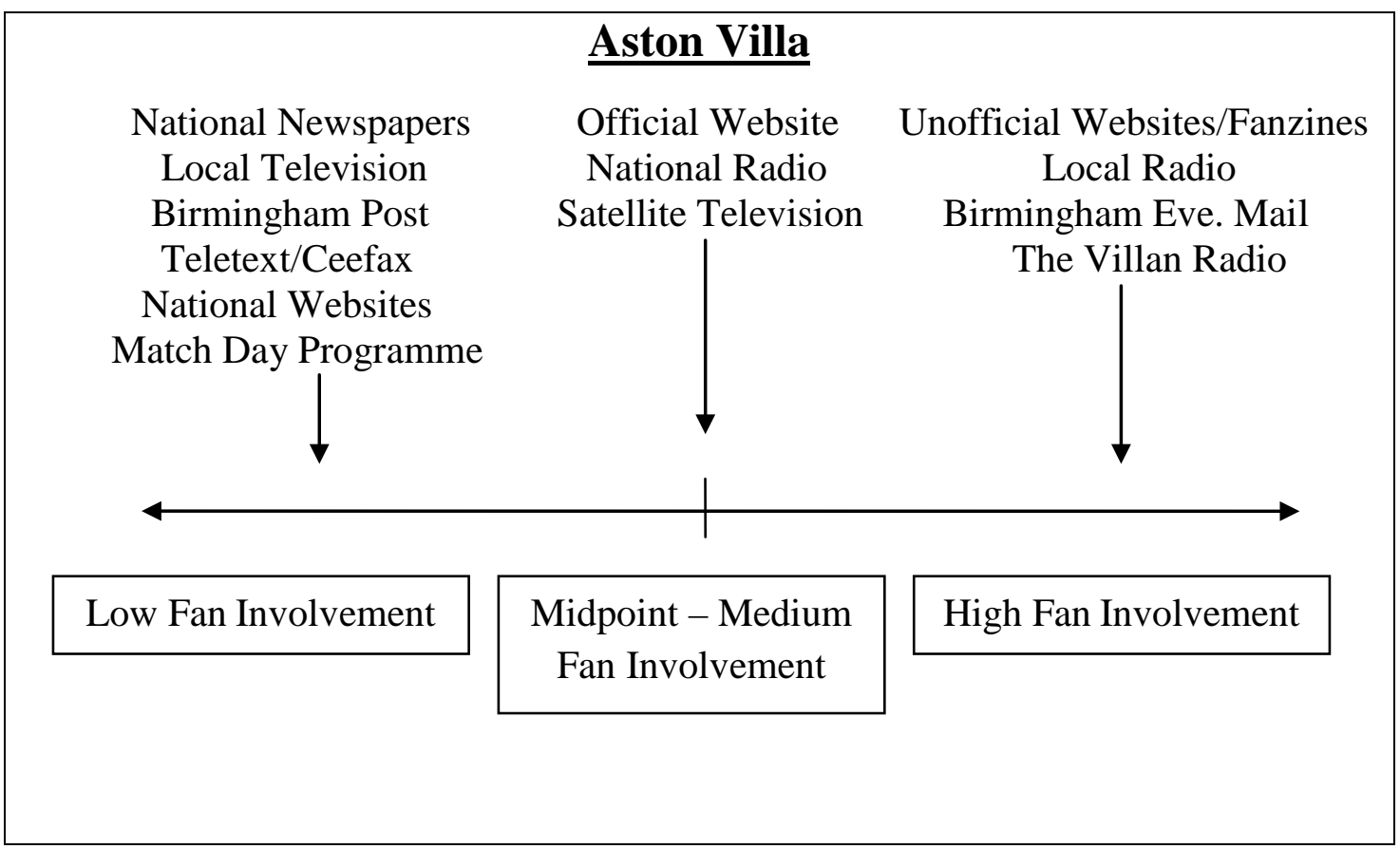

As for Birmingham City, the only difference locally with regards to two-way dialogue was through its contractual exclusivity with Capital Gold/BRMB. Therefore, the club's coverage and exposure was limited on BBC WM as it could only broadcast a minimal amount of match day action (four brief reports in each half). This resulted in a large majority of Birmingham City supporters preferring Capital Gold/BRMB due to the exposure it provided. Highlighting the change of strategy in the Birmingham Evening Mail, the local journalist covering Birmingham City illustrated this was due to clubs releasing news and information on its internal sources first, thus creating a situation where local newspapers:

have to make sure that we are covering the things fans are going to be interested in... we listen to people and what they want and try to be more community based. 
Internally at Birmingham City, a message board service on the official website had been established as well as the opportunity to contact the club and ask them questions. In terms of two-way dialogue, this was the major difference with Aston Villa as every supporter who contacted the club received a personal reply and the club had just begun establishing fans' forums for all supporters to apply to attend. This policy also came through the interviews with the editor of the official website stating:

I always take their views on board because they are the ones who I am trying to reach, they tell me what they want to listen to and what they want to watch and what they want to know...we're an open club that listens to its fans and takes fans [views] on board because there wouldn't be a club if there weren't no fans.

Therefore, to interpret the findings at Birmingham City, the continuum below (Figure 2) summarises the overall level of supporter involvement for both internal and external media:

Figure 2: Level of Supporter Involvement in Media Sources at Birmingham City

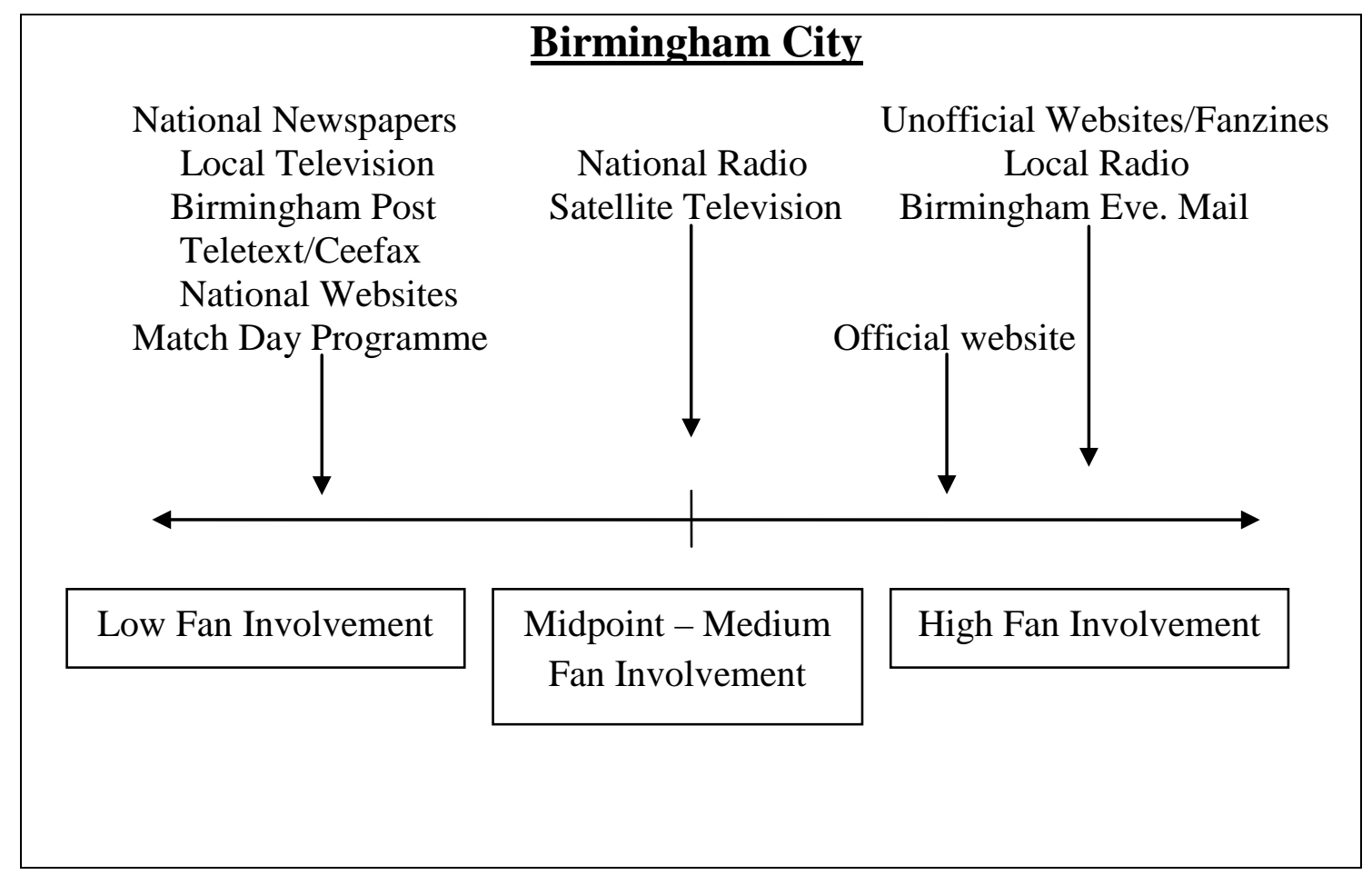

Whilst it has been suggested that 'new' media helped to change the opportunities for two-way dialogue between the media and football supporters, at Coventry City, the Coventry Evening Telegraph had mechanisms in place to interact with supporters since the mid-1990s. One of these was to encourage its readers to write, phone or email in their views on the club, with a selection of them published in the 'Sportsmail' 
section of the newspaper. Furthermore, it also had established a 'Terrace Verdict' section to the newspaper where a small number of supporters rated each player and the team's performance regarding specific matches over the course of the season and again this seemed a popular feature. Similarly to Aston Villa and Birmingham City, the local radio station that provided exclusive live commentary of its matches, BBC Coventry and Warwickshire, also had established a Friday and Saturday night phonein service for supporters to discuss the club and again this was well received. Internally, the club also provided fans' forums as well as opportunities for fans to contact them through both personal correspondence and through the message board service on the official website. To try and involve supporters more in the match day programme, the club had also established, via its official historian and statistician, a 'Where Are They Now?' column where fans were encouraged to write in and inquire about historical facts. Therefore, the continuum below (Figure 3) presents the overall level of supporter involvement for both internal and external media at Coventry City:

Figure 3: Level of Supporter Involvement in Media Sources at Coventry City

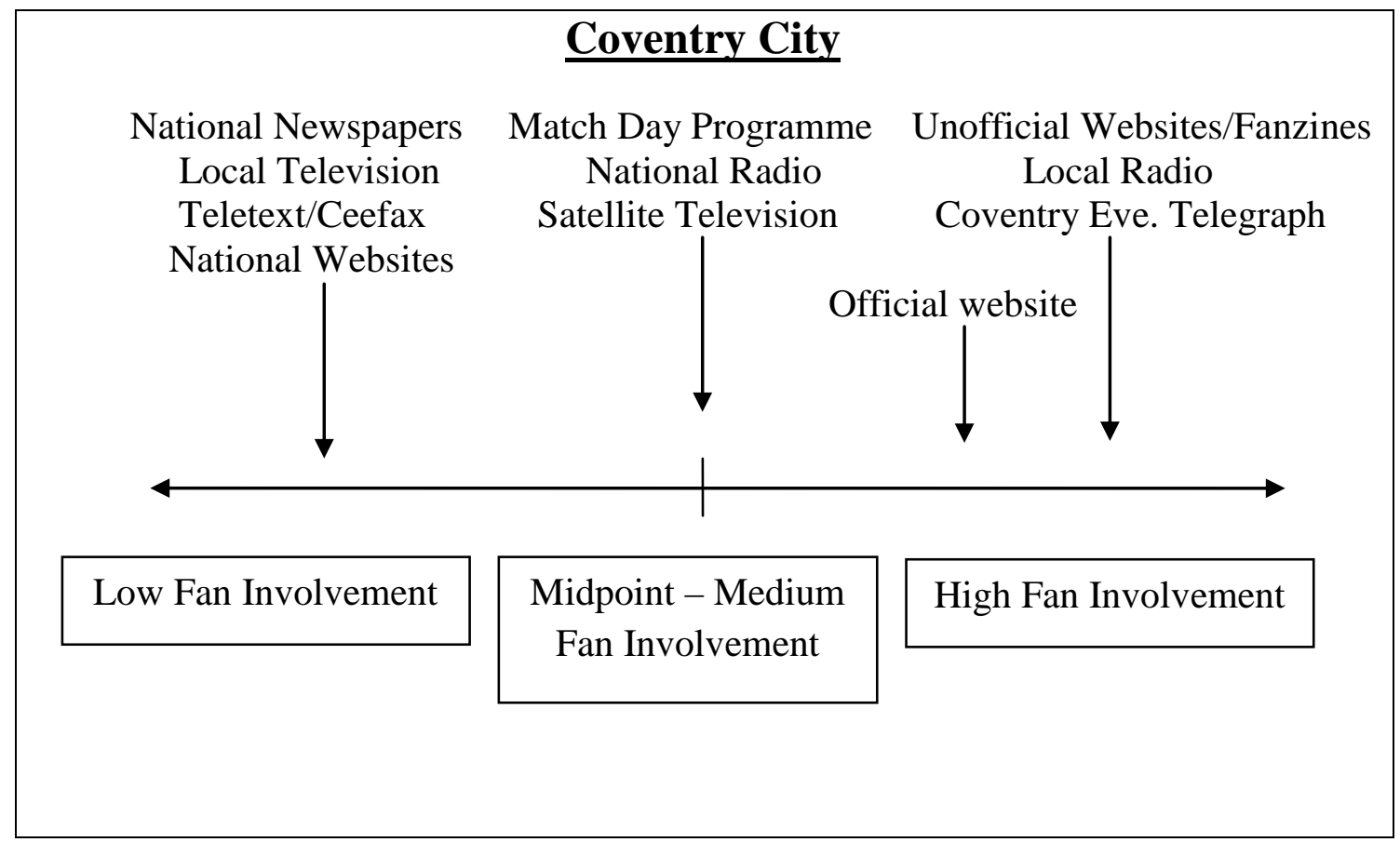

Finally, at the smallest club in this research, Northampton Town, not surprisingly there were some differences in the opportunities for two-way dialogue between a number of internal and external media sources and the club's supporters. Internally, despite only having two employees responsible for communicating with supporters, 
the club provided the same strategy as Birmingham City and Coventry City in establishing two-way dialogue through the media. However, the major difference between this club and the others was that it had established regular fans' forums in which senior club personnel attended. Not surprisingly, this was viewed as a major strategic success in allowing for two-way dialogue to take place; the results of which were then published through a number of media sources for those supporters who could not attend. The close relationship between the club and its supporters was also evident with the well established Supporters' Trust having a page of the match day programme to highlight recent news and provide links to how supporters could get more involved in the club.

Externally, from the 2002/03 season, the Northampton Chronicle and Echo newspaper increased the level of supporter involvement by establishing a 'Fan Zone' section where supporters commented on club issues and recent matches that had taken place. BBC Radio Northampton also provided a phone-in forum for supporters of all the local professional sports teams after the respective matches had finished on a Saturday evening. However, the length of this programme usually depended on the amount of calls received and again highlighted the lower status of the club and local media. The sports editor, for example, stated that at times the number of calls had been so low that the radio station had to use incentives such as providing future match tickets and other offers to attract people to phone-in. Furthermore, unless there was a midweek match there was no football programme provided in the week for supporters as the potential audience was too low to warrant one. Thus, in comparison to the other three case study clubs, external media opportunities for two-way dialogue were low and support the findings of how popular the internal sources were. Therefore, Figure 4 now summarises the level of supporter involvement in the media at Northampton Town: 
Figure 4: Level of Supporter Involvement in Media Sources at Northampton

Town

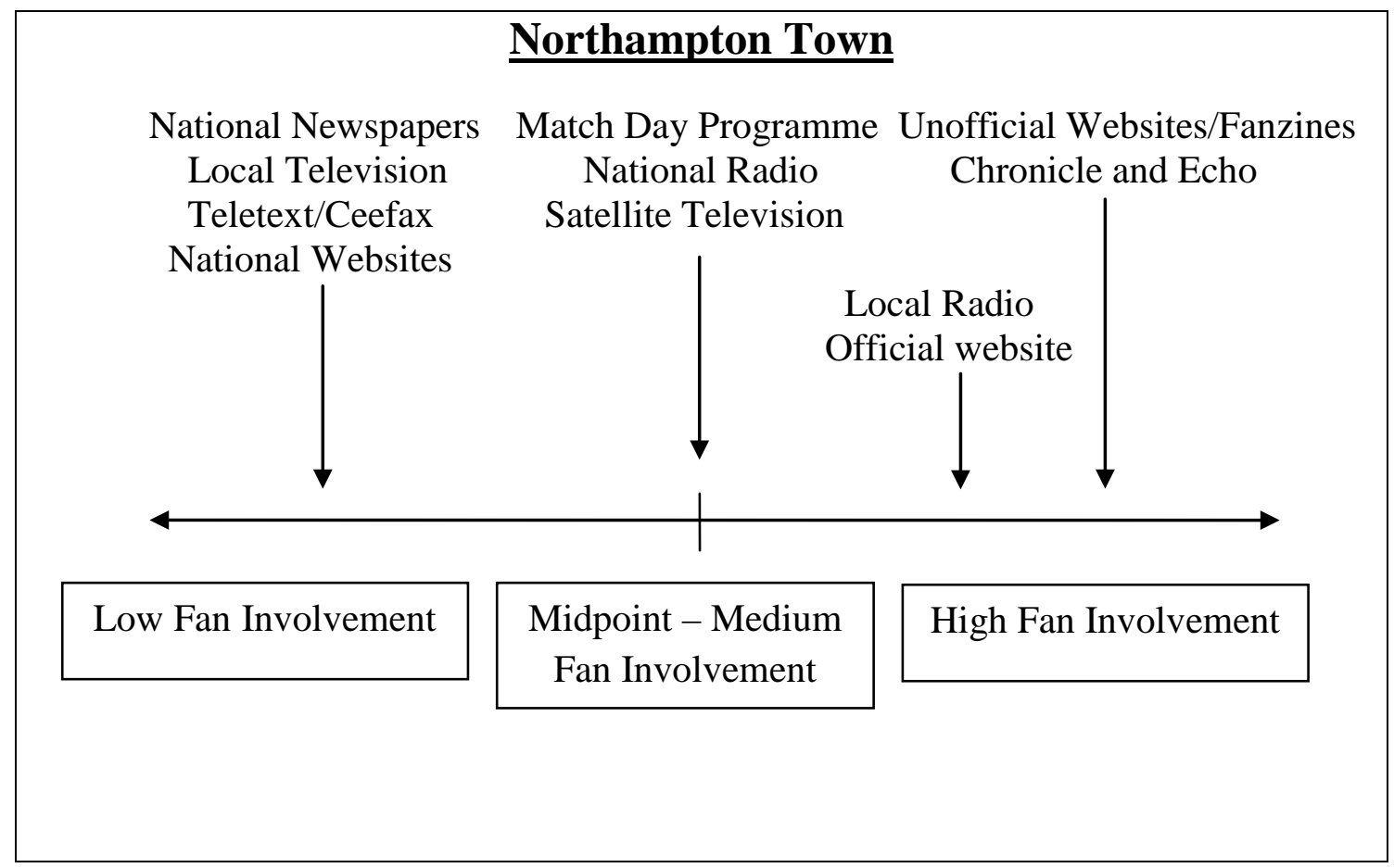

Finally, with regards to the opportunities within the national media for two-way dialogue to take place, Telextet/Ceefax, national websites (BBC Sport and Sky Sports), national radio (Radio Five Live and Talk Sport) and national television (BSkyB's phone-in programme 'You're on Sky Sports') did encourage supporters to air their views. However, this mainly centred on clubs in the Premier League due to the exposure and interest it generated across the world and again illustrates the importance of local media to lower-level clubs.

\section{Conclusion}

Based on the research findings, the development of 'new' media sources and their increasing coverage and focus on football has revolutionised the media-fan relationship. Since Fiske (1989) suggested that during the 1980s popular texts allowed fans to 'actively' construct various readings and interpretations, the media-fan relationship has continued to develop due to the ever increasing number of media sources for them to consume and engage with (as suggested by Abercrombie and Longhurst 1998). One of the biggest changes in this relationship occurred when the 
'new' media not only provided an increasing amount of coverage on the game, but also helped to create two-way dialogue with a number of 'active' supporters.

This has resulted in maintaining football's position at the forefront of popular culture. For instance, the development of 'new' media has created a proliferation of internal and external sources for 'active' supporters not only to gather news and information but also to become involved in discussing clubs. A major development in this was undoubtedly the rapid impact of the Internet. Over 79 per cent of supporters at each club had online access with later research (Premier League survey 2005/06) finding that this figure continues to rise (91 per cent), thus increasing the potential for internal and external media to engage and interact with supporters.

Due to the increasing popularity of football, as well as 'new' media encouraging supporter involvement, 'older' sources such as newspapers and radio had also devised strategies to involve supporters as the relationship becomes more 'interactive'. Most local newspapers (some earlier than others) had developed parts of the football section to supporters writing in and becoming involved in discussing their club. Furthermore, based on the research findings, local radio continued to play an active role in providing commentary on matches whilst at the same time providing an outlet for supporters to phone-in and discuss particular clubs. Nationally, Radio Five Live, Talk Sport and 'You're on Sky Sports' had all developed mechanisms to encourage football supporters to discuss the game and/or specific clubs, but all tend to focus on clubs in the Premier League. Internally, there were differences between the clubs, with Birmingham City, Coventry City and Northampton Town actively encouraging supporter dialogue through the available channels (although this was relatively new). Therefore, it would appear that this not only develops the relationship between the specific media source and the supporters but also aids the connection a supporter feels to 'their' club.

This article has also highlighted the clear importance of both the oldest external source (the local evening newspaper) and one of the newest internal sources (the official club website). Therefore, even in a mass media world the relationship between the local evening newspaper and the supporters at each club remains strong, even at the more exposed clubs such as Aston Villa. One interpretation could be that both sources provided regular opportunities for supporters to contact them and become involved, one from an independent perspective and one from an official perspective. 
In terms of future research, the Football League Supporters survey (2006) highlighted that 93 per cent of all supporters used the official website to find out news and information compared to only 58 per cent who used the local evening newspaper. Thus, what is the situation now with regards to media consumption by supporters? Finally, as this article as indicated, there is an increasing level of involvement between a number of media sources and 'active' supporters. Thus, to what extent has this changed as media sources continue to develop more ways of engaging with its audience?

\footnotetext{
${ }^{1}$ Analysing this relationship is complicated further by the developments in 'new' media as they have increased the number of internal and external sources available to both distribute and gather news and information. However, the ways in which each source (internal and external) encourages supporter involvement is included in this continuum to assist in the overall analysis of the media-fan relationship.

${ }^{2}$ One of the reasons behind this could be because most clubs utilise the services of the digital media company 'Perform' (previously called Premium TV) to develop a website for them. As part of this service, Perform provides the platform and tools that enables clubs to write, manage and develop revenue through the official website.

${ }^{3}$ Capital Gold/BRMB had complete exclusivity on all away matches and five home games of its choice, whilst BBC WM had exclusivity on the other fourteen home matches and provided regular updates on away matches.

${ }^{4}$ Where two sources appear together, they received exactly the same percentage of supporter utilisation.

${ }^{5}$ These two traditional sources were helped by the fact that newspaper stories were available on the Internet, with radio not only available on the Internet, but also digitally as well.

${ }^{6} \mathrm{BBC} \mathrm{WM}$ also broadcast a football programme throughout the week from $7 \mathrm{pm}$ to $10 \mathrm{pm}$ focusing on the local clubs that it provided coverage on. Aston Villa was one of those clubs featured, but because BBC WM had no commentary contract with Birmingham City the club's coverage was obviously limited.
}

\section{References}

Abercrombie, N. and Longhurst, B. (1998) Audiences: A Sociological Theory of Performance and Imagination. London: Sage.

Beech, J., Chadwick, S. and Tapp, A. (2000a) 'Towards a Schema for Football Clubs Seeking an Effective Presence on the Internet’. European Journal for Sport Management, 7: 30-50.

Beech, J., Chadwick, S. and Tapp, A. (2000b) 'Emerging Trends in the Use of the Internet: Lessons from the Football Sector’. Qualitative Market Research, 3 (1): 38-46.

Benoit, K. and Laver, M. (2006) Party Policy in Modern Democracies. London: Routledge.

Blain, N. and Bernstein, A. (2003) Sport, Media, Culture: Global and Local Dimensions. London: Frank Cass. 
Boyle, R. and Haynes, R. (2004) Football in the New Media Age. London: Routledge.

Crawford, G. (2004) Consuming Sport: Fans, Sport and Culture. London: Routledge.

Curran, J. (2002) Media and Power. London: Routledge.

Fiske, J. (1989) Understanding Popular Culture. London: Unwin Hyman.

Football League Supporters Survey (2006) accessed via www.footballleague.com (visited 10 December 2007).

Football Research Unit (1999) 'The Sources of Football Information amongst Everton and Liverpool Fans’. Liverpool University: Liverpool.

Gunter, B., Sancho-Aldridge, J. and Winstone, P. (1994) 'Television: The Public's View', p. 203 in T. O’Sullivan, B. Dutton and P. Rayner (1998) Studying the Media. $2^{\text {nd }}$ Edition, London: Arnold.

Haynes, R. (1995) The Football Imagination: The Rise of the Football Fanzine Culture. Aldershot: Arena.

Horne, J. (2006) Sport in Consumer Culture. Basingstoke: Palgrave Macmillan.

Jenkins, H. (2006) Fans, Bloggers and Gamers: Exploring Participatory Culture. New York: New York University Press.

Laughey, D. (2007) Key Themes in Media Theory. Maidenhead: Open University Press.

Laver, M. and Garry, J. (2000) 'Estimating Policy Positions from Political Texts’. American Journal of Political Science, 44 (3): 619-634.

Mansell, R. (2004) 'Political Economy, Power and the New Media'. New Media and Society, 6 (1): 96-105.

Miles, M.B. and Huberman, M.A. (1984) Qualitative Data Analysis. Thousand Oaks: Sage.

O’Donnell, H. (2003) 'Fitba Crazy? Saturday Super Scoreboard and the Dialectics of Political Debate', pp. 211-226 in A. Bernstein and N. Blain (eds.) Sport, Media, Culture: Global and Local Dimensions. London: Frank Cass.

O’Sullivan, T., Dutton, B. and Rayner, P. (2003) Studying the Media. $3^{\text {rd }}$ Edition, London: Arnold.

Premier League Survey (2005-2006) accessed via www.premierleague.com (visited 24 July 2007).

Redhead, S. (1993) The Passion and the Fashion: Football Fandom in New Europe. Aldershot: Avebury.

Ross, K. and Nightingale, V. (2003) Media and Audiences: New Perspectives. Maidenhead: Open University Press. 
Sandvoss, C. (2005) Fans: The Mirror of Consumption. Cambridge: Polity.

Sir Norman Chester Centre for Football Research, 'Premier League Survey 2001'. University of Leicester.

Social Trends No. 34 (2004). London: Stationery Office.

Spielger, M. (1996) 'Betting on Web Sports', pp. 271-272 in L. Wenner (1998) MediaSport. London: Routledge.

Turner, P. (1999) 'Television and Internet Convergence: Implications for Sport Broadcasting’. Sport Marketing Quarterly, 8 (2): 43-49.

Wenner, L.A. (1998) MediaSport. London: Routledge.

Williams, J. (1999) Is It All Over? Can Football Survive the Premier League. Reading: Garnet.

Williams, J. (2006) 'Protect Me From What I Want': Football Fandom, Celebrity Cultures and 'New' Football in England. Soccer and Society, 7 (1): 96-114. 